\title{
Enhancing Collaborative Treatment Planning with Young People in Mental Health Settings: A Narrative Scoping Review
}

\author{
Katherine Reid \\ Child and Youth Academic Clinical Unit, Logan, \\ Metro South Addiction and Mental Health Services, Queensland, Australia \\ PO Box 6046 Mount Gravatt QLD 4122 \\ E-mail: katherine.reid@health.qld.gov.au \\ Alexandra Olsen (Corresponding Author) \\ Child and Youth Academic Clinical Unit, Logan, \\ Metro South Addiction and Mental Health Services, Queensland, Australia \\ PO Box 6046 Mount Gravatt QLD 4122 \\ E-mail: alexandra.olsen@health.qld.gov.au
}

\begin{abstract}
Pim Kuipers
Centre for Functioning and Health Research, Metro South Health, Queensland, and Hopkins Centre, Griffith University, Queensland, Australia

E-mail: p.kuipers@griffith.edu.au
\end{abstract}

Received: February 18, 2018 Accepted: June 20, 2018 Published: June 22, 2018

doi:10.5296/ijsw.v5i2.12679 URL: http://doi.org/10.5296/ijsw.v5i2.12679

\begin{abstract}
Background: Despite the growing recognition of recovery oriented principles as the preferred way of working with children and young people in a mental health context, translating these principles to practice remains unclear. For mental health clinicians, collaborative treatment
\end{abstract}


planning with young people who experience significant mental health difficulties is complex.

Objective: To identify clinical practices to enhance the participation of young people in mental health treatment planning.

Methods: A scoping review was conducted, using narrative summaries. From 1172 articles identified in a database search and evaluated against inclusion criteria, 22 were included for review. Basic thematic analysis was used to identify key themes from the literature.

Results: The studies reviewed suggested that participatory treatment planning leads to improved processes and outcomes for the young person, the clinician and services. Clinical practices that may enable participation in treatment planning included relational engagement, contracting, therapeutic strategies, strength-based treatment planning and working systematically. A number of consumer, contextual and service delivery factors were also identified which constrain such participation.

Discussion: The categorised findings, ranked according to prominence, provide a useful framework to enable practitioners to maximise the participation of young people in treatment planning. While the findings should be considered as preliminary, due to limitations of studies and methodology, they provide a useful starting point for future studies.

Keywords: Treatment planning, Mental health, Psycho-social, Adolescent, Participation, Partnership

\section{Background}

Within mental health services, the recovery model has been promoted as a cornerstone of effective treatment (Mental Health Standing Committee, 2010). The recovery-oriented approach "allows people flexibility, choice and control over their recovery pathway, and responds to each individual's unique needs, circumstances, life-stage choices and preferences." (Council of Australian Governments, 2012) (p. 14). Unfortunately, aspects of recovery-oriented approaches are not as clear as some mental health clinicians may prefer. One such example is the issue of how clinicians can promote choice and control in treatment planning with child and adolescent consumers.

Recovery practice principles are clearly identifiable in key international (Farkas, 2007), national (Council of Australian Governments, 2017), and state (Queensland Mental Health Commission, 2014), mental health policy. Whilst personal recovery can occur without professional involvement, (Anthony, 1993) recovery-oriented policy directives highlight the relationship between the mental health clinician and the consumer as a means to facilitate recovery (Department of Health and Aging, 2013). It is usually based on respectful, collaborative therapeutic relationships (Council of Australian Governments, 2012), which ensure consumer self-determination and person- centred practice (Council of Australian Governments, 2012; Department of Health and Aging, 2013). Within most policy documents consumers are seen as active participants (Council of Australian Governments, 2012, 2017).

Since the 1990's recovery-oriented approaches have been seen as the optimal way of working with children and their care givers within child and youth mental health services (James, 2007). However since they are based on concepts developed within the adult consumer movement, it is unclear how they should be translated to child and youth mental service settings (Palmquist, Patterson, O'Donovan, \& Bradley, 2017). Literature reviews pertaining to 
personal recovery (Leamy, Bird, Le Boutillier, Williams, \& Slade, 2011), and treatment engagement through person-centred care (Dixon, Holoshitz, \& Nossel, 2016) have been based on adult mental health consumers. Interestingly, some literature on youth participation in service development (Day, 2008; Howe, Batchelor, \& Bochynska, 2011) has acknowledged that "participation" is different for young people (James, 2007), however there are few guides to enable meaningful participation in treatment planning. As a result, this narrative scoping review was undertaken to explore the literature pertaining to collaborative treatment planning with young people. The purpose of this study was to identify how collaborative treatment planning with young people translates to actual practice in a Child and Youth Mental Health setting.

\section{Methods}

Having noted that much of the research on boosting the participation of young people in treatment planning was mixed and not experimental in nature, the authors drew from scoping review methods which incorporate a broad range of literature, and which can be useful for identifying key concepts (McKinstry, Brown, \& Gustafsson, 2014) across disciplines (Rozas $\&$ Klein, 2010). Scoping reviews typically survey different types of literature to provide an overview and to describe the nature of evidence on a topic (Arksey \& O'Malley, 2005). They are particularly suited to summarising literature on topics which may not be amenable to systematic review (McKinstry et al., 2014), as well as complex or emerging areas (S. Anderson, Allen, Peckham, \& Goodwin, 2008; Arksey \& O'Malley, 2005).

The current review was conducted as a practice-based research initiative by mental health clinicians (KR and AO) working with an experienced research mentor (PK) (Daudt, Van Mossel, \& Scott, 2013). The process was informed by established frameworks for conducting scoping reviews (Arksey \& O'Malley, 2005), particularly those using a collaborative, group approach (Levac, Colquhoun, \& O’Brien, 2010), describing outcomes in narrative style.

The impetus for this study was the clinical experience of the first two authors, social workers in a child and youth mental health service that provides therapeutic and behaviour support services for children and young people (Queensland Health, 2016). Recognising that many consumers have difficulties with establishing trusting relationships, and articulating their concerns and hopes for treatment, this service seeks continued improvement in consumer engagement and close collaboration with key stakeholders. The authors undertook a review of current literature with the aim of highlighting practices that may maximise the participation of young people in treatment planning. In light of their practice concerns, the research team met as a whole to refine a research question, which was: "What are the clinical practices that support participation of young people in treatment planning?"

Based on the research question, a number of search terms were identified and tested for relevance of output through trial bibliographic database searches. After consideration, a set of search terms was agreed upon (Table 1). Due to the team's interest in identifying a range of potential sources, the search was limited to English language articles, but no limits were set on date range (prior to 2016), article type, journal subset, geographic subset, gender or age (which was addressed with greater specificity through the search terms) (Table 1). 
Table 1. Agreed search terms

\begin{tabular}{ll}
\hline Category & Search terms selected \\
\hline Service Context & $\begin{array}{l}\text { mental health OR mental illness OR psychiat* OR behaviour* } \\
\text { disorder OR behavior* disorder }\end{array}$ \\
AND & AND \\
Population focus & young person OR Youth OR adolescent OR teenage* OR child* \\
& OR minor \\
AND & AND \\
Treatment focus & treatment plan* OR case plan* OR care plan* OR recovery plan* \\
& OR intervention plan OR therap* plan \\
AND & AND \\
Desired outcome & engagement OR collaborat* OR participat* OR empower* \\
\hline
\end{tabular}

In preliminary stages, trial searches were undertaken on ERIC, SocINDEX, PsycINFO and CINAHL-Complete. Based on outputs of these initial searches it was noted that most searches yielded a high rate of irrelevant "hits". It was agreed that the search would be based on the bibliographic database that yielded the most pertinent hits (namely PsycINFO). This was a pragmatic decision, balancing potential hits against feasibility within clinical practice.

\subsection{Study Selection}

The search yielded 1172 hits. After removal of one duplicate, the titles of all 1171 hits were read by KR and AO together, and were screened against inclusion and exclusion criteria. Articles were included on the basis of their discussion and/or evaluation of clinical practices that support the participation of young people, adults, families and/or their caregivers in treatment planning, or more generally within mental health practice. If articles were clearly not relevant, based on their title, they were excluded. In cases where there was some possibility of relevance, the abstract was retrieved and read by KR and AO together, to determine suitability. Consensus decision making was applied in these screening sessions and 1143 articles were excluded at title and/or abstract level (Figure 1). 


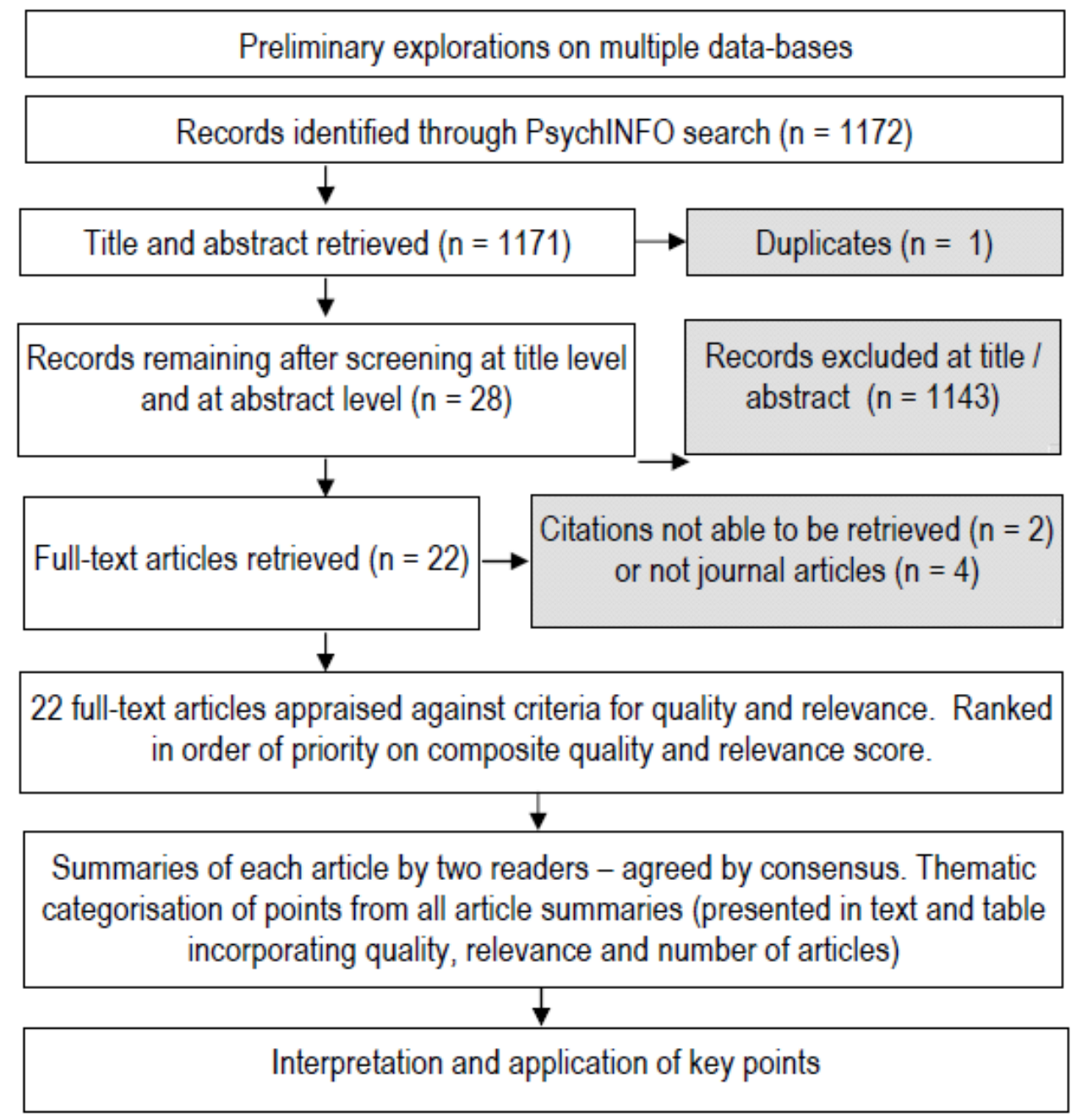

Figure 1. Practice based scoping review - flow diagram

Full texts of the remaining 28 articles were sought. Four out of 28 were found not to be journal articles. Two articles were inaccessible, through academic libraries in South East Queensland. The remaining 22 were retrieved and downloaded. Each article was read by two team members independently, and key findings pertaining to the research were documented.

Descriptive information (author and year of publication, study population, type of article/methodology, concept / definition of participation) was extracted from each article and tabulated. A summary of included articles is noted at Appendix 1. To facilitate "thematic construction", that is the identification of key themes prominent in the literature (Arksey \& O'Malley, 2005), detailed findings were recorded in a qualitative data table comprising:

- Outcomes of participation

- Enablers of participation

- Constraints to participation

- Clinical practice issues / results 


\section{Macrothink}

International Journal of Social Work

ISSN 2332-7278

2018, Vol. 5, No. 2

Thematic analysis comprised highlighting and extracting relevant information pertaining to these key themes, summarising the themes into categories and then identifying subthemes and key points.

Finally, based on the quality and number of articles that pertained to each theme, a "prominence" rating was assigned (Table 2). That is, according to previously established criteria (Appendix 2), each article was weighted against criteria for methodological quality and relevance to the question and context. Based on rankings of quality, relevance and the number of articles that pertained to each theme, a 'prominence' rating was assigned.

\section{Results}

The review and analysis of selected articles identified three main categories presented here, namely; outcomes or benefits, factors which enable, and factors which constrain collaborative treatment planning with young people (Table 2).

\subsection{Outcomes of Collaborative Treatment Planning}

Outcomes of collaborative treatment planning described in reviewed articles were diverse. While there were no causally demonstrated outcomes, the reviewed articles suggested that more personalised treatment plans (Chorpita \& Daleiden, 2014; Toivakka, 2012), and improved coordination of care (Holum, 2012; Pavkov, Lourie, Hug, \& Negash, 2010) were linked with engaging mental health consumers in treatment planning. These were seen as enhancing the young person's interactions with the health care system (Day, 2008; Howe et al., 2011; Mirabito, 2006) by increasing their control and influence (Amodeo \& Collins, 2007; Day, 2008; Holum, 2012; LeFrançois, 2008; Prilleltensky, Peirson, Gould, \& Nelson, 1997; Walker, Thorne, Powers, \& Gaonkar, 2009) and improving their quality of life.

Table 2. Prominence of key subthemes

\begin{tabular}{|c|c|c|}
\hline Theme & Statement & Prominence* \\
\hline \multirow[t]{5}{*}{ Outcomes } & $\begin{array}{l}\text { May improve young people's interaction with the health care } \\
\text { system }\end{array}$ & $\bullet \bullet$ (High) \\
\hline & $\begin{array}{l}\text { May improve the quality of life of young people with mental } \\
\text { health difficulties }\end{array}$ & $\bullet$ (Med) \\
\hline & $\begin{array}{l}\text { When caregivers / family are engaged, it increases their } \\
\text { understanding of the child's needs }\end{array}$ & • (Low) \\
\hline & Upholds the human rights of the child & $\bullet(\mathrm{Med})$ \\
\hline & $\begin{array}{l}\text { Failure to involve young people in treatment planning can lead } \\
\text { to their unwillingness to engage in mental health services }\end{array}$ & $\bullet$ (Med) \\
\hline \multirow[t]{3}{*}{ Enablers } & $\begin{array}{l}\text { Building respectful, inclusive and collaborative relationships } \\
\text { between clinician and young person }\end{array}$ & $\bullet \bullet(\mathrm{Med})$ \\
\hline & Promoting client autonomy & $\bullet \bullet$ (High) \\
\hline & $\begin{array}{l}\text { Treating young people as "equal partners" in treatment } \\
\text { planning }\end{array}$ & $\bullet \bullet($ High $)$ \\
\hline
\end{tabular}


Involving family and key stakeholders in setting treatment $\bullet$ (Med) goals

Using client-centred and family-centred practice principles

Offering warmth, understanding and empathy

Actively negotiating and contracting roles between $\bullet$ (Med) professionals, young people and their families

Demonstrating good communication by asking young people $\bullet \bullet(H i g h)$ questions that seek to understand their perspectives

Solution focused, strengths-based and motivational • (Low) interviewing processes (which can support greater self-reflection for young people)

Individualised planning that incorporates young person's and • (Low) family's strengths, specific and achievable goals

Ongoing review of client perception of goal attainment

Using procedural guidelines and checklists that prompt • (Low) clinicians to reflect on client engagement throughout the planning process

Staff training to enhance service practices

Constraints Young people feeling disempowered to participate in treatment $\bullet \bullet \bullet$ (High) planning

Young people varying in their understanding of their mental $\bullet \bullet(\mathrm{Med})$ health and ability to articulate accurate information

Clinician approaches that perpetuate power imbalances

Young people being excluded from treatment planning by the $\bullet$ (Med) clinician on the basis of their "best interests" being served

Clinicians' feeling overwhelmed

Caregivers' undermining young peoples' participation in $\bullet$ (Low) treatment planning

Limited understanding and/or commitment at service level of $\bullet$ (Med) how to support young peoples' participation

An over-reliance on traditional medical models favouring ••(Med) "expert" driven intervention

* Prominence is a composite rating by the authors, based on: (a) Ranked article quality, (b) Ranked article relevance, and (c) Number of articles that contributed information on the subtheme. 
Specific outcomes that were associated with collaborative approaches included:

- Improved behavioural and mental health outcomes for young people in care (J. A. Anderson, McIntyre, \& Somers, 2004; Howe et al., 2011; Toivakka, 2012).

- $\quad$ Enhanced personal meaning and satisfaction (Holum, 2012; Schauer, Everett, del Vecchio, \& Anderson, 2007), and increased sense of connectedness and belonging (Howe et al., 2011) for the young person.

- $\quad$ Increased likelihood of the young person remaining in treatment (Walker et al., 2009; Warnick, Bearss, Weersing, Scahill, \& Woolston, 2014).

- New skills and an increased sense of mastery (Day, 2008; Holum, 2012; Howe et al., 2011; Mirabito, 2006), enhanced ability to manage their own goals (Holum, 2012), as well as better functional outcomes (Kjellberg, Kåhlin, Haglund, \& Taylor, 2012; Pavkov et al., 2010; Schauer et al., 2007).

- Increased trust in helpers (Holum, 2012).

- $\quad$ Family members developing a greater understanding of the young person's needs through participation (Crais, 1993).

Interestingly, one article described participation in treatment planning as an outcome in and of itself (Day, 2008). Shared decision-making was seen as a critical component of recovery, or as a key means of upholding the human rights of the child in the treatment context (Day, 2008; Schauer et al., 2007).

\subsection{Enablers of Collaborative Treatment Planning}

Reviewed articles reflected an array of factors which enable or facilitate greater engagement in treatment planning. Fundamentally, they emphasised the need for a respectful and collaborative relationship between the clinician and young person (Holum, 2012; Oruche, Downs, Holloway, Draucker, \& Aalsma, 2014). When a young person feels secure they are better able to participate in formulating goals (Green, Wisdom, Wolfe, \& Firemark, 2012; Holum, 2012). Eight articles emphasised the importance of clinicians developing trust, respecting and promoting client autonomy (Amodeo \& Collins, 2007; Crais, 1993; Green et al., 2012; Holum, 2012; Oruche et al., 2014; Schauer et al., 2007; Song \& Omar, 2009; Toivakka, 2012), and encouraging clients to make their own decisions regarding their treatment (Green et al., 2012; Holum, 2012; Walker et al., 2009). For this to occur, it was suggested that the process of treatment planning should focus on understanding the client's experience, independent of their ability to express their needs (Kjellberg et al., 2012). Practical strategies included deeming children competent until proven otherwise, and taking into account the young person's developmental level (J. A. Anderson et al., 2004; LeFrançois, 2008), which may differ from their chronological age.

A personal rather than diagnostic approach to working with young people in a mental health setting is needed (Green et al., 2012). A shift from a pathology focus to normalising young people's behaviour in an adolescent framework (Amodeo \& Collins, 2007; Green et al., 2012), and reframing avoidant coping strategies, was emphasised (Amodeo \& Collins, 2007). It is clear, however, that the strategies should be flexible, age-appropriate and reflect youth culture and lifestyle (Green et al., 2012; Mirabito, 2006). 
Other person-centred approaches included:

- Offering a sense of calm (Holum, 2012), warmth, understanding, empathy, personal respect, honesty, authenticity and unconditional positive regard (Day, 2008; Green et al., 2012; Kjellberg et al., 2012; Oruche et al., 2014; Schauer et al., 2007).

- Listening and relating in an open and inclusive way to convey shared values with the young person (Day, 2008; Oruche et al., 2014; Schauer et al., 2007).

- Identifying the young person's readiness for change, starting "where the client is at" (Amodeo \& Collins, 2007; Green et al., 2012; Mirabito, 2006) and seeing the clients as "experts" in their own care (Brown et al., 2010).

- Instilling hope during the assessment process (Crais, 1993).

One article highlighted the importance of caregivers supporting the treatment goals generated by young people (Mirabito, 2006). It was accentuated that parental understanding of treatment goals promoted and increased young people's engagement generally (Oruche et al., 2014; Warnick et al., 2014).

From the service provider perspective, where consumer participation was noted it was often linked with a consumer focused perspective. Reviewed articles highlighted the need for services to reflect client dignity, connectedness, continuity, and opportunities (Amodeo \& Collins, 2007). To promote participation, services should focus on building strengths and competencies (Amodeo \& Collins, 2007), including cultural competencies (J. A. Anderson et al., 2004). Service providers should learn from consumers and caregivers as a form of professional development for clinicians (Cleary, Freeman, \& Walter, 2006). Reviewed studies noted that enhanced participation is enabled when the clinician is clear about their rationale (Day, 2008), whether that is to engage the young person more fully (Amodeo \& Collins, 2007; Crais, 1993; Day, 2008; Holum, 2012; LeFrançois, 2008; Oruche et al., 2014), or to find new solutions for the mental health issues that they may encounter (Toivakka, 2012).

Practical strategies of relevance to service providers that were noted in the review included:

- From the outset, spending time getting to know the young person (Green et al., 2012). This may include allowing sufficient time to engage with them (Green et al., 2012; Mirabito, 2006), as well as flexible appointments (Day, 2008). It may also require finding modes of communication that enable them to express their views (LeFrançois, 2008), encouraging them to express their ideas (Holum, 2012), but recognising they may have limited self-reflective capacity (Toivakka, 2012).

- Tailoring services to respond to young people's individual needs (Chorpita \& Daleiden, 2014; Crais, 1993; Mirabito, 2006; Warnick et al., 2014), and providing opportunities for them and their caregivers to frankly articulate their views and expectations of participation (Cleary et al., 2006).

- Consulting young people on who they would like in their treatment team (Brown et al., 2010) and then ensuring that they participate in case reviews (LeFrançois, 2008), using bi-directional approaches (Brown et al., 2010; Warnick et al., 2014).

- Conversely, it was also noted that multi-disciplinary teams are desirable (Pavkov et al., 2010), but require adequate interagency co-ordination (J. A. Anderson et al., 2004; Mirabito, 2006), and reflectiveness (Pavkov et al., 2010). 
- Staff training should emphasise key theories and practices of consumer and caregiver participation (Brown et al., 2010; Cleary et al., 2006; LeFrançois, 2008) to develop a supportive organisational culture (Cleary et al., 2006).

- A knowledge management system which facilitates sharing information about treatment options with clients and their families to work towards more informed choices (Chorpita \& Daleiden, 2014) is also beneficial.

As noted in Table 2, a key theme in the articles reviewed was the importance of negotiating and contracting roles between professionals, young people and their families (Crais, 1993; Holum, 2012; Mirabito, 2006; Warnick et al., 2014). Such contracts between young people and clinicians should be collaborative, specific, and culturally appropriate (Mirabito, 2006). Clinicians should use contracts to clarify young people's preferences and values (Schauer et al., 2007) and to balance responsibility through negotiation (Holum, 2012). This may include explaining and clarifying the assessment (Toivakka, 2012) and treatment options and processes (Day, 2008; Schauer et al., 2007), focusing on immediate needs, and identifying barriers to the treatment plan (Warnick et al., 2014). It may be important to explore the young person's readiness for change (Amodeo \& Collins, 2007), any past difficulties with adherence to treatment plans, as well as beliefs and fears about their illness (Song \& Omar, 2009).

Good communication was seen as a requirement for this contracting process, and included asking questions to understand the young person's problems, expectations and perspective, and encouraging the young person to ask questions (Crais, 1993; Green et al., 2012; Holum, 2012; Kjellberg et al., 2012; Schauer et al., 2007; Song \& Omar, 2009; Warnick et al., 2014). Utilising rating scales of problem severity to develop a shared understanding of the problem and its effects was noted (Warnick et al., 2014). Other aspects included, ensuring voluntary participation (Toivakka, 2012) and obtaining consent (Green et al., 2012), discussing confidentiality policies (Green et al., 2012), and gaining feedback from the young person after assessment and treatment planning (Toivakka, 2012).

The review noted that therapeutic skills, where they were described, were drawn from solution-focused (J. A. Anderson et al., 2004) and motivational interviewing (Amodeo \& Collins, 2007) approaches. For example, "exception finding" was recommended to find new self-narratives or solutions (Toivakka, 2012), and fostering self-reflection was noted as a strategic approach (Amodeo \& Collins, 2007). Further, using an individualised and/or strengths-based care plan was associated with greater engagement in treatment planning, ideally as a developmentally individualised approach that incorporates both individual and family strengths and needs (J. A. Anderson et al., 2004; Brown et al., 2010). Strengths-based care planning seeks achievable goals (Amodeo \& Collins, 2007; J. A. Anderson et al., 2004; Chorpita \& Daleiden, 2014; Holum, 2012), and invites the young person to describe what they want to change and how (Amodeo \& Collins, 2007; Song \& Omar, 2009).

In general, reviewed articles recommended educating the young person, their family and key stakeholders about the mental health diagnosis (J. A. Anderson et al., 2004), and setting a precedent of ensuring their collaborative involvement in setting treatment goals (J. A. Anderson et al., 2004; Mirabito, 2006; Oruche et al., 2014; Song \& Omar, 2009). This requires "astute observation skills, the ability to use self-reflection and self-analysis, the development of active listening skills, the ability to refrain from professionally directed 
solutions generation.... and perhaps most of all, patience and flexibility" (p. 38), (Crais, 1993). Systemically engaging multiple stakeholders requires professionals to explore multiple ways to reach an end point, to remain neutral if there is a conflict (Toivakka, 2012), and to find ways to balance the young person's and the family's priorities (Crais, 1993). This was seen as contributing to building relationships and improving choices (Crais, 1993).

Two articles noted the importance of resources to support young people's participation in treatment planning. For example, using young people's stories and testimonials can provide examples of resources used by others to support such decision-making processes (Schauer et al., 2007). In a more formal sense, forms and checklists which prompt clinicians to reflect (Day, 2008) and summary letters following treatment planning sessions (Day, 2008) may be beneficial. Decision making aids which inform the young person and their caregivers of "the risks and benefits of treatment choices" and clarify their personal values were also described (Day, 2008).

Finally, four articles referred to service features which may enhance young people's participation in treatment planning. Experienced, well organised and effective staff are crucial (Holum, 2012), and time-limited interventions are recommended (Mirabito, 2006). Service evaluation is important and includes measuring whether a service is meaningfully engaging young people in treatment planning (Walker et al., 2009), and reviewing treatment plans to ensure that the logic of decision making and planning is clear (Chorpita \& Daleiden, 2014; Mirabito, 2006).

\section{Constraints to Collaborative Treatment Planning}

When young people feel disempowered, intimidated or lack confidence, their ability to participate in treatment planning is limited (Holum, 2012; Howe et al., 2011; LeFrançois, 2008; Schauer et al., 2007; Walker et al., 2009). This may limit their ability "to provide accurate information about the history and phenomenology of their emotional states and symptoms ... (and) ... to develop collaborative treatment goals" (Day, 2008) (p. 4). Likewise, if they have concerns over confidentiality or their parent's reaction (Day, 2008), they are unlikely to engage fully. If a young person lacks adequate knowledge about their mental health and the possible solutions (Kjellberg et al., 2012) or if are not ready to change (Amodeo \& Collins, 2007), it may also hinder meaningful engagement in treatment planning.

Reviewed studies suggest that mental health clinicians can adversely affect a young person's participation in treatment planning when they perpetuate power imbalances (Schauer et al., 2007; Walker et al., 2009), seek to maintain authority or use coercion (Schauer et al., 2007), or use jargon (Cleary et al., 2006). If they focus to much on reducing the young person's symptoms (Cleary et al., 2006) or "behaviours" (Green et al., 2012; Song \& Omar, 2009; Toivakka, 2012) or work "by the book or the clock" (Green et al., 2012), it constrains engagement. Likewise, if they are perceived as a "parental agent" (Green et al., 2012), privileging parental perspectives (Day, 2008) and focusing on the family (Amodeo \& Collins, 2007), they may not foster adequate engagement from the young person. Clinicians' attitudes, class or world-view (Schauer et al., 2007) or their interpretation of legislation (LeFrançois, 2008; Monson \& Thurley, 2011) such as "in the name of protection of the vulnerable" (p. 213) (LeFrançois, 2008), may also constrain their ability to engage young people. 
Reviewed articles noted that where the family or carers focus solely on symptom reduction (Cleary et al., 2006), it can be a barrier to engagement. If they are in crisis (Song \& Omar, 2009) or feel threatened or resentful of the attention from the mental health clinician, it may compromise the young person's participation in treatment planning (Mirabito, 2006). It was also noted that issues such as socioeconomic status and ethnicity of the carer or household may be linked with limited participation and premature termination (Warnick et al., 2014).

For the service, confusion over confidentiality policies (Cleary et al., 2006), the absence of a specific processes, and limited organisational commitment, were noted as constraints (Howe et al., 2011; Warnick et al., 2014). Likewise, too much emphasis on the goals of the referrer may overshadow the young person's goals in treatment planning (J. A. Anderson et al., 2004). Reviewed articles indicated that inhospitable clinic environments (Mirabito, 2006), time and workload pressures (Cleary et al., 2006; Kjellberg et al., 2012), clinicians feeling overwhelmed by large and complicated caseloads (Mirabito, 2006), as well as the drive for standardisation (Day, 2008), may stifle innovative attempts to boost the young person's participation (Chorpita \& Daleiden, 2014).

Systemic issues which may impact on the participation of young people in treatment planning include constant organisational change (Chorpita \& Daleiden, 2014) and high levels of staff turnover (Oruche et al., 2014). Where the service adopts an overly medicalised approach, focusing too much on "expert" perspectives (Crais, 1993; LeFrançois, 2008; Schauer et al., 2007) and evidence (Chorpita \& Daleiden, 2014; Day, 2008) to inform treatment planning, it may be difficult for young people's views to be heard.

\section{Discussion}

As reflected in Table 2, the reviewed literature reflected numerous dimensions of relevance to clinicians seeking to engage young people in treatment planning. Reviewed articles outlined a number of outcomes and benefits of enhancing participation, which may serve as motivation for clinicians and services. The enablers and constraints drawn from the literature systematically outline issues from the perspective of the young person, families and carers, clinicians and service providers. In particular, the review showed a strong focus on basic communication skills, and the benefit of client-centred and family-centred practice.

Acknowledging the variety of important issues and strategies identified in the current review, it is clear that enhancing participation is incremental and multi-dimensional. Unless young people are seen as experts in their own mental health and are treated as "equal partners" in treatment planning, collaboration will not be fully realised. The role of a mental health clinician is to facilitate engagement, taking into account their social and emotional development. Engagement strategies need to be modified based on the service setting (i.e. inpatient or community setting) and the acuity of the young person's mental health concerns. Offering a range of ways for young people to express themselves, and asking questions to elicit young peoples' understandings is crucial to this process. Within a service, it may be beneficial to clearly articulate a spectrum of participation that takes into consideration the nature and extent of psychological, social, circumstantial, emotional, and mental health factors that impact on a young person's lives and experience of dis/empowerment. Collaborative treatment planning occurs in the social context of a young person's life. Consequently, a key practice implication is the importance of developing effective 
relationships with both the young person, and the key people in their life. Effective relationships enable the young person to feel secure and ensure a co-ordinated approach to treatment planning. Organisational structures, policies, procedures and culture play an essential role in supporting the mental health clinician in their role of building partnerships with young people. Service development consultation with young people is beginning to occur, however further consultation with young people regarding clinical processes including mental health assessment and treatment planning is required. Recovery-oriented service provision is only possible within a broader organisational context that values meaningful partnerships with young people.

From a methodological perspective, it is noted that many of the reviewed articles were descriptive, and lacked more rigorous comparisons or critical analyses of this topic. Clear strategies to enable young people to meaningfully engage in treatment planning have been only partially been articulated to date. There is a need to more critically analyse ways to optimise children and young people's involvement in healthcare choices and decision-making (Day, 2008). Indeed, even the expectation that young people are capable and willing to assume a certain degree of power and responsibility within the relationship is a contemporary Western viewpoint which others may not hold (Kjellberg et al., 2012). However, given that engaging young people and their caregivers in treatment planning is core to many mental health policies and practice guidelines, the lack of comparative and critical analyses in this area is cause for some concern. It is hoped that the current review might be a constructive step in identifying and consolidating key concepts.

While this scoping review has identified a number of factors pertaining to collaborative treatment planning, it is recognised that the findings are by no means exhaustive. There were a number of limitations to the current study. First, as a clinician led, practice-based study, the database search was limited for pragmatic reasons. While this meant that not every potential source was included, it was mitigated by the selection of the most pertinent database, and the review of over 1000 articles. Second, the studies reviewed were mixed. Some reviewed articles were descriptive, some were opinion pieces and some were service evaluation project summaries. As a result, they were difficult to compare and evaluate. In response, we chose a narrative process, and we also sought to acknowledge and maximise the value of the articles by integrating ratings of quality and relevance (Appendix 2) which were then reflected in the main outcomes table (Table 2).

\section{Conclusion}

Collaborative treatment planning is a key component to increase young peoples' agency, to support their recovery, and improve their quality of life across the life span. Despite the growing recognition of recovery-oriented practice principles, and young peoples' right to be an equal partner in their own treatment plan, limited research has been done that reveals effective strategies to enhance collaborative treatment planning. The realities of collaborative treatment planning in a Child and Youth Mental Health setting are complex. Further research that acknowledges the complexities involved in engaging severely disengaged young people is necessary. Building on the current review, studies which articulate practices and skills for working with disengaged young people (potentially using case studies) would extend contemporary knowledge. This may include exploring issues of context and timing of actions 
to enhance engagement in treatment planning for young people. Future practice-based research will enhance clinicians' ability to promote partnership with young people in complex mental health settings.

\section{References}

Amodeo, M., \& Collins, M. E. (2007). Using a positive youth development approach in addressing problem-oriented youth behavior. Families in Society: The Journal of Contemporary Social Services, 88(1), 75-85. https://doi.org/10.1606/1044-3894.3594

Anderson, J. A., McIntyre, J. S., \& Somers, J. W. (2004). Exploring the experiences of successful completers of a system of care for children and their families through case narratives. Journal of Family Social Work, 8(1), 1-25. https://doi.org/10.1300/J039v08n01_01

Anderson, S., Allen, P., Peckham, S., \& Goodwin, N. (2008). Asking the right questions: scoping studies in the commissioning of research on the organisation and delivery of health services. Health Res Policy Syst, 6(7), 1-12. https://doi.org/10.1186/1478-4505-6-7

Anthony, W. A. (1993). Recovery From Mental Illness: The Guiding Vision of the Mental Health Service System in the 1990s. Psychosocial Rehabilitation Journal, 16(4), 11-23. https://doi.org/10.1037/h0095655

Arksey, H., \& O'Malley, L. (2005). Scoping studies: towards a methodological framework. International journal of social research methodology, 8(1), 19-32. https://doi.org/10.1080/1364557032000119616

Brown, J. D., Barrett, K., Ireys, H. T., Allen, K., Pires, S. A., \& Blau, G. (2010). Family-driven youth-guided practices in residential treatment: Findings from a national survey of residential treatment facilities. Residential Treatment for Children \& Youth, 27(3), 149-159. https://doi.org/10.1080/0886571X.2010.500137

Chorpita, B. F., \& Daleiden, E. L. (2014). Structuring the collaboration of science and service in pursuit of a shared vision. Journal of Clinical Child and Adolescent Psychology, 43(2), 323-338. https://doi.org/10.1080/15374416.2013.828297

Cleary, M., Freeman, A., \& Walter, G. (2006). Carer participation in mental health service delivery. International Journal of Mental Health Nursing, 15(3), 189-194. https://doi.org/10.1111/j.1447-0349.2006.00422.x

Council of Australian Governments. (2012). The Roadmap for National Mental Health Reform, 2012-2022. Australian Government.

Council of Australian Governments. (2017). The Fifth National Mental Health Plan, 2017 2022. Australian Government.

Crais, E. R. (1993). Families and professionals as collaborators in assessment. Topics in Language Disorders, 14(1), 29-40. https://doi.org/10.1097/00011363-199311000-00005

Daudt, H. M., Van Mossel, C., \& Scott, S. J. (2013). Enhancing the scoping study methodology: a large, inter-professional team's experience with Arksey and O'Malley's framework. BMC Medical Research Methodology, $13(1), \quad 48$. https://doi.org/10.1186/1471-2288-13-48 
Day, C. (2008). Children's and young people's involvement and participation in mental health care. Child and Adolescent Mental Health, 13(1), 2-8. https://doi.org/10.1111/j.1475-3588.2007.00462.x

Department of Health and Aging. (2013). A national framework for recovery oriented mental health services: Policy and theory. Australian Government. Retrieved from http://www.ahmac.gov.au/cm

Dixon, L. B., Holoshitz, Y., \& Nossel, I. (2016). Treatment engagement of individuals experiencing mental illness: review and update. World Psychiatry, 15(1), 13-20. https://doi.org/10.1002/wps.20306

Farkas, M. (2007). The vision of recovery today: what it is and what it means for services. World Psychiatry, 6(2), 68.

Green, C. A., Wisdom, J. P., Wolfe, L., \& Firemark, A. (2012). Engaging youths with serious mental illnesses in treatment: STARS study consumer recommendations. Psychiatric Rehabilitation Journal, 35(5), 360-368. https://doi.org/10.1037/h0094494

Holum, L. C. (2012). "Individual plan" in a user-oriented and empowering perspective: A qualitative study of "individual plans" in Norwegian mental health services. Nordic Psychology, 64(1), 44-57. https://doi.org/10.1080/19012276.2012.693725

Howe, D., Batchelor, S., \& Bochynska, K. (2011). Finding our way: Youth participation in the development and promotion of youth mental health services on the NSW Central Coast. Advances in Mental Health, 10(1), 20-28. https://doi.org/10.5172/jamh.2011.10.1.20

James, A. M. (2007). Principles of youth participation in mental health services. Medical Journal of Australia, 187(7), S57.

Kjellberg, A., Kåhlin, I., Haglund, L., \& Taylor, R. R. (2012). The myth of participation in occupational therapy: Reconceptualizing a client-centred approach. Scandinavian Journal of Occupational Therapy, 19(5), 421-427. https://doi.org/10.3109/11038128.2011.627378

Leamy, M., Bird, V., Le Boutillier, C., Williams, J., \& Slade, M. (2011). Conceptual framework for personal recovery in mental health: systematic review and narrative synthesis.

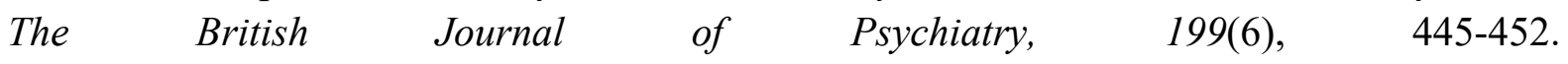

https://doi.org/10.1192/bjp.bp.110.083733

LeFrançois, B. A. (2008). " It's Like Mental Torture": Participation and Mental Health Services. The International Journal of Children's Rights, 16(2), 211-227. https://doi.org/10.1163/157181808X301809

Levac, D., Colquhoun, H., \& O'Brien, K. K. (2010). Scoping studies: advancing the methodology. Implement Sci, 5(1), 1-9. https://doi.org/10.1186/1748-5908-5-69

McKinstry, C., Brown, T., \& Gustafsson, L. (2014). Scoping reviews in occupational therapy: The what, why, and how to. Australian occupational therapy journal, 61(2), 58-66. https://doi.org/10.1111/1440-1630.12080

Mental Health Standing Committee. (2010). National standards for mental health services. Department of Health and Ageing. Retrieved from http://www.health.gov.au/internet/main/publishing.nsf/content/CFA833CB8C1AA178CA257 BF0001E7520/\$File/servst10v2.pdf 
Mirabito, D. M. (2006). Revisiting Unplanned Termination: Clinicians' Perceptions of Termination From Adolescent Mental Health Treatment. Families in Society, 87(2), 171-180. https://doi.org/10.1606/1044-3894.3510

Monson, K., \& Thurley, M. (2011). Consumer participation in a youth mental health service. Early Intervention in Psychiatry, 381-388. https://doi.org/10.1111/j.1751-7893.2011.00309.x

Oruche, U. M., Downs, S., Holloway, E., Draucker, C., \& Aalsma, M. (2014). Barriers and facilitators to treatment participation by adolescents in a community mental health clinic. Journal of Psychiatric and Mental Health Nursing, 21(3), 241-248. https://doi.org/10.1111/jpm.12076

Palmquist, L., Patterson, S., O'Donovan, A., \& Bradley, G. (2017). Protocol: A grounded theory of 'recovery' - perspectives of adolescent users of mental health services. BMJ open, 7(7), e015161. https://doi.org/10.1136/bmjopen-2016-015161

Pavkov, T. W., Lourie, I. S., Hug, R. W., \& Negash, S. (2010). Improving the quality of services in residential treatment facilities: A strength-based consultative review process. Residential Treatment for Children \& Youth, 27(1), 23-40. https://doi.org/10.1080/08865710903508050

Prilleltensky, I., Peirson, L., Gould, J., \& Nelson, G. (1997). Planning mental health services for children and youth: Part I-A value-based approach. Evaluation and Program Planning, 20(2), 163-172. https://doi.org/10.1016/S0149-7189(96)00047-X

Queensland Health. (2016). Evolve Therapeutic Service. Queensland Health. Retrieved from http://qheps.health.qld.gov.au/metrosouthmentalhealth/html/evolve_service.htm

Queensland Mental Health Commission. (2014). Improving mental health and wellbeing Queensland Mental Health, Drug and Alcohol Strategic Plan 2014-2019. Queensland Health,. Rozas, L. W., \& Klein, W. C. (2010). The Value and Purpose of the Traditional Qualitative Literature Review. Journal of Evidence-Based Social Work, 7(5), 387-399. https://doi.org/10.1080/15433710903344116

Schauer, C., Everett, A., del Vecchio, P., \& Anderson, L. (2007). Promoting the value and practice of shared decision-making in mental health care. Psychiatric Rehabilitation Journal, 31(1), 54-61. https://doi.org/10.2975/31.1.2007.54.61

Song, M., \& Omar, H. A. (2009). Discovering the complexities of adolescent compliance to treatment. International Journal of Adolescent Medicine and Health, 21(1), 3-8.

Toivakka, H. (2012). Collaborative assessment on an adolescent psychiatric ward: A psychotic teenage girl. In S. E. Finn, C. T. Fischer, \& L. Handler (Eds.), Collaborative/therapeutic assessment: A casebook and guide. (pp. 335-354). Hoboken, NJ, US: John Wiley \& Sons Inc.

Walker, J. S., Thorne, E. K., Powers, L. E., \& Gaonkar, R. (2009). Development of a scale to measure the empowerment of youth consumers of mental health services. Journal of Emotional and Behavioral Disorders, 18(1), 51-59. https://doi.org/10.1177/1063426609337388 
Warnick, E. M., Bearss, K., Weersing, V. R., Scahill, L., \& Woolston, J. (2014). Shifting the treatment model: Impact on engagement in outpatient therapy. Administration and Policy in Mental Health and Mental Health Services Research, 41(1), 93-103. https://doi.org/10.1007/s10488-012-0439-3

\section{Appendix 1. Article Characteristics}

\begin{tabular}{|c|c|c|c|c|c|}
\hline Author & Aim & Setting & Methods & $\begin{array}{l}\text { Sample } \\
\text { Size }\end{array}$ & $\begin{array}{l}\text { Research } \\
\text { Tool }\end{array}$ \\
\hline $\begin{array}{l}\text { Amodeo \& } \\
\text { Collins } \\
(2007)\end{array}$ & $\begin{array}{lr}\text { Provide } & \text { practice } \\
\text { guidelines } & \text { for Positive } \\
\text { Youth } & \text { Development } \\
\text { approach } & \end{array}$ & $\begin{array}{l}\text { Adolescent substance use } \\
\text { in out-of-home care }\end{array}$ & $\begin{array}{l}\text { Service } \\
\text { evaluation }\end{array}$ & N/A & N/A \\
\hline $\begin{array}{l}\text { Anderson et } \\
\text { al. (2004) }\end{array}$ & $\begin{array}{l}\text { Explore experience of } \\
\text { community based care }\end{array}$ & $\begin{array}{l}\text { Child and adolescent } \\
\text { community mental health }\end{array}$ & $\begin{array}{l}\text { Case } \\
\text { narratives }\end{array}$ & $\begin{array}{l}3 \text { children } \\
\text { and } \\
\text { adolescents }\end{array}$ & $\begin{array}{l}\text { Semi-struct } \\
\text { ured } \\
\text { interview }\end{array}$ \\
\hline $\begin{array}{l}\text { Brown et } \\
\text { al. (2010) }\end{array}$ & $\begin{array}{l}\text { Examine the adoption of } \\
\text { youth guided care }\end{array}$ & $\begin{array}{l}\text { Residential adolescent } \\
\text { mental health treatment }\end{array}$ & $\begin{array}{l}\text { Qualitative } \\
\text { study }\end{array}$ & $\begin{array}{l}293 \\
\text { residential } \\
\text { treatment } \\
\text { facilities }\end{array}$ & Survey \\
\hline $\begin{array}{l}\text { Chorpita \& } \\
\text { Daleiden } \\
(2014)\end{array}$ & $\begin{array}{l}\text { Highlight models } \\
\text { connecting science and } \\
\text { individualised care }\end{array}$ & Children's mental health & $\begin{array}{l}\text { Conceptual } \\
\text { discussion }\end{array}$ & $\mathrm{N} / \mathrm{A}$ & $\mathrm{N} / \mathrm{A}$ \\
\hline $\begin{array}{l}\text { Cleary et al. } \\
(2006)\end{array}$ & $\begin{array}{l}\text { Highlight challenges of } \\
\text { facilitating carer } \\
\text { participation }\end{array}$ & Mental health services & $\begin{array}{l}\text { Opinion } \\
\text { piece }\end{array}$ & $\mathrm{N} / \mathrm{A}$ & N/A \\
\hline $\begin{array}{l}\text { Crais } \\
(1993)\end{array}$ & $\begin{array}{l}\text { Note barriers and } \\
\text { enablers of collaborative } \\
\text { assessment }\end{array}$ & $\begin{array}{l}\text { Child community health } \\
\text { services }\end{array}$ & $\begin{array}{l}\text { Opinion } \\
\text { piece }\end{array}$ & N/A & $\mathrm{N} / \mathrm{A}$ \\
\hline Day (2008) & $\begin{array}{l}\text { Note factors that } \\
\text { encourage young } \\
\text { people's involvement in } \\
\text { clinical processes. }\end{array}$ & $\begin{array}{l}\text { Child and adolescent } \\
\text { mental health services }\end{array}$ & $\begin{array}{l}\text { Opinion } \\
\text { piece }\end{array}$ & NA & NA \\
\hline $\begin{array}{l}\text { Green et al. } \\
(2012)\end{array}$ & $\begin{array}{l}\text { Identify methods of } \\
\text { engaging youth in mental } \\
\text { health services }\end{array}$ & $\begin{array}{l}\text { Inpatient and community } \\
\text { adult mental health }\end{array}$ & $\begin{array}{l}\text { Qualitative } \\
\text { study }\end{array}$ & 177 people & $\begin{array}{l}\text { In-depth } \\
\text { semi-struct } \\
\text { ured } \\
\text { interviews }\end{array}$ \\
\hline $\begin{array}{l}\text { Holum } \\
(2012)\end{array}$ & $\begin{array}{l}\text { Description of Individual } \\
\text { Plan process }\end{array}$ & $\begin{array}{l}\text { Community and inpatient } \\
\text { mental health }\end{array}$ & $\begin{array}{l}\text { Qualitative } \\
\text { study }\end{array}$ & $\begin{array}{l}10 \\
\text { adolescents } \\
\text { or adults }\end{array}$ & $\begin{array}{l}\text { Semi-struct } \\
\text { ured } \\
\text { interviews }\end{array}$ \\
\hline $\begin{array}{l}\text { Howe et al. } \\
\text { (2011) }\end{array}$ & $\begin{array}{l}\text { Describe development, } \\
\text { implementation and } \\
\text { evaluation of youth }\end{array}$ & $\begin{array}{l}\text { Adolescent community } \\
\text { mental health }\end{array}$ & $\begin{array}{l}\text { Service } \\
\text { evaluation }\end{array}$ & $\begin{array}{l}16 \\
\text { adolescents }\end{array}$ & $\begin{array}{l}\text { Group } \\
\text { interview, } \\
\text { question-na }\end{array}$ \\
\hline
\end{tabular}


alliance

ires,

Kjellberg et Explore levels of Adult mental health

records

al. (2012)

participation in mental

health

Qualitat
study

Qualitative 285

Occupation

al

Therapists

LeFrançois

(2008)

Mirabito

(2006)

Observe and document Adolescent inpatient Ethnograph
implementation of mental health unit and ic study
children's participation day patient facilities

Young

Obser-vatio

rights

unplanned terminations

of treatment

\begin{tabular}{|c|c|c|c|c|c|}
\hline $\begin{array}{l}\text { Monson \& } \\
\text { Thurley } \\
(2011)\end{array}$ & $\begin{array}{l}\text { Explore consumer } \\
\text { participation in early } \\
\text { intervention service }\end{array}$ & $\begin{array}{l}\text { Community } \\
\text { health service }\end{array}$ & $\begin{array}{l}\text { Service } \\
\text { evaluation }\end{array}$ & N/A & N/A \\
\hline $\begin{array}{l}\text { Oruche et } \\
\text { al. (2014) }\end{array}$ & $\begin{array}{l}\text { Identify organisation } \\
\text { factors that influence } \\
\text { participation }\end{array}$ & $\begin{array}{l}\text { Adolescent community } \\
\text { mental health }\end{array}$ & $\begin{array}{l}\text { Qualitative } \\
\text { study }\end{array}$ & $\begin{array}{l}12 \\
\text { adolescent } \\
\text { caregiver } \\
\text { dyads } \\
\end{array}$ & $\begin{array}{l}\text { Focus } \\
\text { group }\end{array}$ \\
\hline $\begin{array}{l}\text { Pavkov et } \\
\text { al. (2010) }\end{array}$ & $\begin{array}{l}\text { Identify service } \\
\text { improvement in } \\
\text { treatment planning. }\end{array}$ & $\begin{array}{l}\text { Adolescents - residential } \\
\text { treatment facilities }\end{array}$ & $\begin{array}{l}\text { Descriptive } \\
\text { case study- } \\
\text { program } \\
\text { evaluation }\end{array}$ & $\begin{array}{l}182 \\
\text { files }\end{array}$ & $\begin{array}{l}\text { Un-structur } \\
\text { ed } \\
\text { Interview }\end{array}$ \\
\hline $\begin{array}{l}\text { Prilleltensk } \\
\text { y et al. } \\
(1997)\end{array}$ & $\begin{array}{l}\text { Explore value-based } \\
\text { approach to mental } \\
\text { health planning }\end{array}$ & $\begin{array}{l}\text { Child community mental } \\
\text { health service }\end{array}$ & $\begin{array}{l}\text { Service } \\
\text { evaluation }\end{array}$ & 467 & $\begin{array}{l}\text { Question-n } \\
\text { aire }\end{array}$ \\
\hline $\begin{array}{l}\text { Schauer et } \\
\text { al. (2007) }\end{array}$ & $\begin{array}{l}\text { Explore shared decision } \\
\text { making in health and } \\
\text { mental health care }\end{array}$ & $\begin{array}{l}\text { Health and mental health } \\
\text { services }\end{array}$ & $\begin{array}{l}\text { Opinion } \\
\text { piece }\end{array}$ & NA & NA \\
\hline $\begin{array}{l}\text { Song \& } \quad \& \\
\text { Omar } \\
(2009)\end{array}$ & $\begin{array}{l}\text { Explore challenges in } \\
\text { enhancing adolescent } \\
\text { treatment compliance }\end{array}$ & $\begin{array}{l}\text { Adolescent } \\
\text { services }\end{array}$ & $\begin{array}{l}\text { Opinion } \\
\text { piece }\end{array}$ & N/A & N/A \\
\hline $\begin{array}{l}\text { Toivakka } \\
\text { (2012) }\end{array}$ & $\begin{array}{l}\text { Describe collaborative } \\
\text { assessment process }\end{array}$ & $\begin{array}{l}\text { Adolescent inpatient } \\
\text { mental health }\end{array}$ & $\begin{array}{l}\text { Case } \\
\text { narrative }\end{array}$ & $\begin{array}{l}1 \\
\text { adolescent }\end{array}$ & N/A \\
\hline $\begin{array}{l}\text { Walker et } \\
\text { al. (2009) }\end{array}$ & Scale development & $\begin{array}{l}\text { Adolescent inpatient or } \\
\text { outpatient mental health }\end{array}$ & $\begin{array}{l}\text { Quantitativ } \\
\mathrm{e}\end{array}$ & 185 youths & Survey \\
\hline $\begin{array}{l}\text { Warnick et } \\
\text { al. (2014) }\end{array}$ & $\begin{array}{l}\text { Evaluate early attrition } \\
\text { under specific treatment } \\
\text { planning strategies }\end{array}$ & $\begin{array}{l}\text { Child and adolescent } \\
\text { outpatient mental health } \\
\text { setting }\end{array}$ & $\begin{array}{l}\text { Service } \\
\text { evaluation }\end{array}$ & $\begin{array}{l}321 \text { parents } \\
\text { and youths }\end{array}$ & Self-report \\
\hline
\end{tabular}


5. IMPLICATIONS Does the report draw clear links to practice, policy or further research?

\begin{tabular}{|ll|l|ll|l|ll|}
\hline $\mathbf{1}$ & Not really & $\mathbf{2}$ & $\mathbf{3}$ Somewhat & $\mathbf{4}$ & $\mathbf{5}$ & Very much \\
\hline
\end{tabular}

Consider

- Are the benefits of the research highlighted?

- How well have the authors linked the results to everyday clinical practice/health service delivery?

\section{TALLY: Quality Score:}

\section{Relevance:}

6. CONTENT How relevant is the paper to your review question?

\begin{tabular}{|c|c|c|c|}
\hline 1 & Not relevant & 2 & 3 \\
\hline
\end{tabular}

Consider

-What are the stated aims and content area of the research?

- How generally relevant are these to the topic of your review?

- How directly relevant is this paper to your questions?

7. FOCUS How focused is the paper on your professional area (e.g Social Work, Child Therapy)

\begin{tabular}{|c|c|c|c|c|}
\hline 1 Not really & 2 & 3 Somewhat & 4 & 5 Very much \\
\hline
\end{tabular}

8. CONTEXT Is the context of the research comparable with your practice context?

\begin{tabular}{l|l|l|l|l|}
\hline $\mathbf{1}$ Not really & $\mathbf{2}$ & $\mathbf{3}$ Somewhat & $\mathbf{4}$ & $\mathbf{5}$ Very much \\
\hline $\begin{array}{l}\text { Consider } \\
\bullet\end{array}$ \\
How similar are things like client demographics, service model, resource environment, etc.?
\end{tabular}

9. UTILITY How useable is the information provided in the paper for your practice?

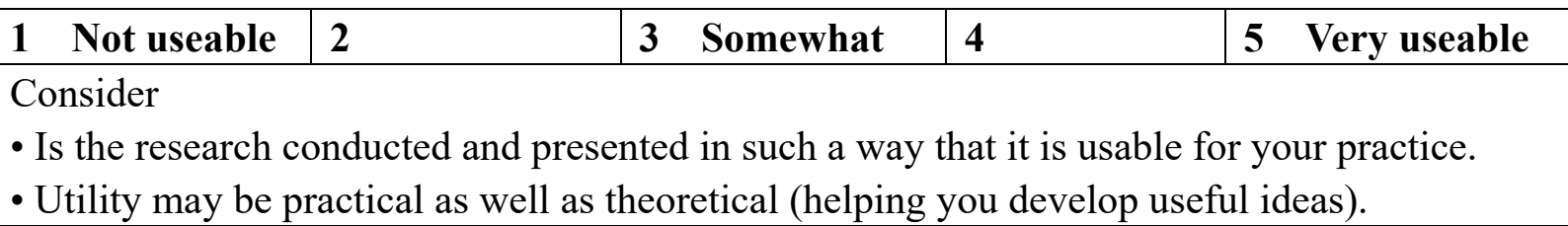


TALLY: Relevance Score:

Summary of findings/key points that relate to the review question:

\section{Copyright Disclaimer}

Copyright reserved by the author(s).

This article is an open-access article distributed under the terms and conditions of the Creative Commons Attribution license (http://creativecommons.org/licenses/by/3.0/). 